\title{
RTCB-1 Mediates Neuroprotection via XBP-1 mRNA Splicing in the Unfolded Protein Response Pathway
}

\author{
Arpita Ray, ${ }^{1}$ Siyuan Zhang, ${ }^{1}$ Courtney Rentas, ${ }^{1}$ Kim A. Caldwell, ${ }^{1,2}$ and Guy A. Caldwell ${ }^{1,2}$ \\ ${ }^{1}$ Department of Biological Sciences, The University of Alabama, Tuscaloosa, Alabama 35487, and ${ }^{2}$ Departments of Neurobiology and Neurology and Center \\ for Neurodegeneration and Experimental Therapeutics, University of Alabama at Birmingham, Birmingham, Alabama 35294
}

Parkinson's disease (PD), the second most prevalent neurodegenerative disorder, is characterized by the degeneration of dopamine (DA) neurons and age-dependent formation of protein inclusions that contain the $\alpha$-synuclein ( $\alpha$-syn) protein. RNA interference (RNAi) screening using Caenorhabditis elegans identified RTCB-1, an uncharacterized gene product, as one of several significant modifiers of $\alpha$-syn protein misfolding. RTCB-1 is the worm ortholog of the human HSPC117 protein, a component of RNA trafficking granules in mammalian neurons. Here we show that RTCB-1 protects C. elegans DA neurons from age-dependent degeneration induced by human $\alpha$-syn. Moreover, neuronal-specific RNAi depletion of $r t c b$ - 1 enhanced $\alpha$-syn-induced degeneration. Similar results were obtained when worms were exposed to the DA neurotoxin 6-hydroxydopamine. HSPC117 has been characterized recently as an essential subunit of the human tRNA splicing ligase complex. tRNA ligases have alternative functions in RNA repair and nonconventional mRNA splicing events. For example, in yeast, unconventional splicing of $H A C 1$, a transcription factor that controls the unfolded protein response (UPR), is mediated by a tRNA ligase. In C. elegans, we demonstrate that RTCB-1 is necessary for $x b p$ - 1 (worm homolog of HAC1) mRNA splicing. Moreover, using a RNA ligase-dead mutant, we determine that the ligase activity of worm RTCB-1 is required for its neuroprotective role, which, in turn, is mediated through XBP-1 in the UPR pathway. Collectively, these studies highlight the mechanistic intersection of RNA processing and proteostasis in mediating neuroprotection.

Key words: alpha-synuclein; C. elegans; dopamine; neuroprotection; Parkinson's; RNA

\section{Introduction}

The pathogenesis of Parkinson's disease (PD) involves the loss of dopamine (DA) neurons in the midbrain and manifests through mechanisms such as mitochondrial defects and protein misfolding, leading to endoplasmic reticulum (ER) stress and proteasome dysfunction (Yacoubian and Standaert, 2009). Another characteristic of $\mathrm{PD}$ is the accumulation of $\alpha$-synuclein ( $\alpha$-syn) into inclusions termed Lewy bodies (Dickson et al., 2009). Mutation or multiplication of the wild-type (WT) $\alpha$-syn locus causes misfolding of $\alpha$-syn protein, leading to aggregation (Uversky, 2007). Discerning molecular mechanisms underlying neurodegeneration is a prerequisite for identifying functional modifiers with translational potential for PD.

We have established previously Caenorhabditis elegans as an animal model to investigate PD, wherein overexpression of WT

Received May 13, 2014; revised 0ct. 1, 2014; accepted 0ct. 17, 2014.

Author contributions: A.R., S.Z., K.A.C., and G.A.C. designed research;A.R., S.Z., and C.R. performed research;A.R., S.Z., and C.R. contributed unpublished reagents/analytic tools; A.R., S.Z., K.A.C., and G.A.C. analyzed data; A.R., K.A.C., and G.A.C. wrote the paper.

We thank Laura Berkowitz, Xiaohui Yan, and Susan DeLeon for their assistance and expert advice in the progress of this project. Some C. elegans strains were provided by the Caenorhabditis Genetics Center, which is funded by National Institutes of Health Office Research Infrastructure Programs (Grant P40 OD010440). This research was funded by National Institutes of Health Grants R15 NS075684 (G.A.C.) and R15 NS078728 (K.A.C.). Other support came from a Howard Hughes Medical Institute Undergraduate Science Program Grant to The University of Alabama (C.R.) and the Parkinson's Support Group of Huntsville.

The authors declare no competing financial interests.

Correspondence should be addressed to Guy A. Caldwell, Department of Biological Sciences, The University of Alabama, Tuscaloosa, AL 35487-0344. E-mail: gcaldwel@ua.edu.

DOI:10.1523/JNEUROSCI.1945-14.2014

Copyright $\odot 2014$ the authors $\quad 0270-6474 / 14 / 3416076-10 \$ 15.00 / 0$ human $\alpha$-syn driven under a DA neuron-specific promoter causes age- and dose-dependent neurodegeneration (Cao et al., 2005; Hamamichi et al., 2008). This correlates with human genetics, in which multiplication of the WT $\alpha$-syn locus leads to familial PD (Singleton et al., 2003). Hamamichi et al. (2008) conducted a large-scale RNA interference (RNAi) screen in C. elegans that identified several genetic modifiers of $\alpha$-syn toxicity, including one uncharacterized open-reading frame, F16A11.2, now annotated as $r t c b-1$.

RTCB-1, encoding a 505 aa protein, contains a highly conserved RtcB domain, common to the RtcB family of proteins present in eukaryotes, bacteria, and archaebacteria. RtcB proteins are atypical RNA ligases with broad substrate specificity implicated in tRNA splicing and repair (Englert et al., 2011; Tanaka et al., 2011; Chakravarty et al., 2012). Human HSPC117 can bind to AU-rich elements within mRNA (Rousseau et al., 2002) and was characterized recently as an essential subunit of the tRNA splicing ligase complex (Popow et al., 2011). Although HSPC117 is ubiquitously expressed in human tissues, a functional role in neurons was suggested by its presence in RNA transport granules in mouse brain extracts (Kanai et al., 2004).

Besides tRNA splicing, RNA ligases have been demonstrated to function in RNA repair and nonconventional mRNA splicing events. One such event is the unconventional splicing of HAC1 mRNA, encoding a yeast transcription factor that controls the unfolded protein response (UPR). Interestingly, the bacterial homolog of RTCB-1, RtcB, can functionally complement yeast 
tRNA ligase splicing activity (Sidrauski et al., 1996; Tanaka et al., 2011). The UPR pathway is conserved from yeast to mammals (Iwawaki et al., 2001), in which XBP1, a homolog of HAC1, is cleaved by IRE1 endonuclease (Shen et al., 2001). During ER stress, the unspliced $X B P 1$ transcript is alternatively spliced to produce an active version of XBP1 mRNA (Calfon et al., 2002). $\mathrm{XBP} 1$ mediates transcription of chaperone proteins such as BiP/ Grp78 and facilitates the exit and degradation of misfolded proteins via ER-associated protein degradation (ERAD). In $C$. elegans, XBP-1 activates UPR genes involved in folding, secretion, ER biogenesis, and autophagy. There are no homologs of yeast tRNA ligase in either mammals or C. elegans, thus the factor responsible for splicing of XBP1 in metazoan systems has remained unknown (Wang and Shuman, 2005). Here we report RTCB- 1 as a functional mediator of $x b p-1$ splicing and describe its role in neuroprotection.

\section{Materials and Methods}

Plasmid construction. $r t c b-1$ and $x b p-1$ were amplified from genomic DNA isolated from N2 Bristol nematodes using Phusion high-fidelity polymerase. An N-terminal FLAG tag sequence was added to $r t c b-1 /$ $x b p-1$ cDNA during the PCR amplification process. Using Gateway Technology (Life Technologies), PCR-amplified constructs were cloned into plasmid entry vector pDONR221 by BP reaction, and the constructs were further cloned into Gateway expression vector pDEST-DAT-1 (Cao et al., 2005). To generate the point mutant RTCB-1 C122A, TagMaster site-directed mutagenesis kit (GM Biosciences) was used. The constructs were verified by DNA sequencing.

C. elegans strains. Nematodes were maintained using standard procedures (Brenner, 1974). We obtained the following strains from the Caenorhabditis Genetics Center: rtcb-1 $(g k 451)$ and $x b p-1(z c 12)$. Strain BY250 [vtIs7 ( $\left.\left.\mathrm{P}_{\text {dat- } 1}:: \mathrm{GFP}\right)\right]$ was a generous gift from Randy Blakely (Vanderbilt University, Nashville, TN). The isogenic strain UA44 [baIn11 $\left(\mathrm{P}_{\text {dat }-1}:: \alpha\right.$-syn, $\left.\left.\mathrm{P}_{\text {dat }-1}:: \mathrm{GFP}\right)\right]$ expresses $\alpha$-syn and GFP in the DA neurons. UA196 [sid-1(pk3321); baIn33 ( $\mathrm{P}_{\text {dat }-1}::$ sid-1, $\mathrm{P}_{\text {myo-2 }}::$ mCherry); baIn11], UA197 [sid-1 (pk3321); uIS69 [ $\mathrm{P}_{\text {unc-119 }}::$ sid-1, $\mathrm{P}_{\text {myo-2 }}::$ Cherry); baIn11],

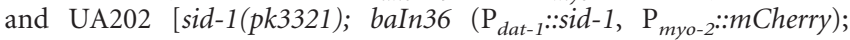
$\left.v t I s 7\left(\mathrm{P}_{\text {dat }-1}:: \mathrm{GFP}\right)\right]$ were generated as described previously (Harrington et al., 2012). UA196 expresses $\alpha$-syn, GFP, and SID- 1 in the DA neurons. UA202 expresses only GFP and SID-1 in the DA neurons. Both are sensitive to RNAi specifically in the DA neurons. UA197 is a pan-neuronal specific RNAi strain expressing $\alpha$-syn and GFP in DA neurons and SID-1 in all neurons. Three independent stable transgenic lines were generated by injecting $\mathrm{P}_{\text {dat- } 1}:$ rtcb-1, along with a phenotypic marker

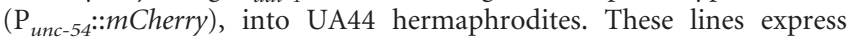
RTCB-1 in the DA neurons and mCherry in the body wall muscle cells, as a phenotypic marker. One of the stable lines, with the most significant level of neuroprotection against $\alpha$-syn-induced degeneration (data not shown), was further integrated into the $C$. elegans genome by UV irradiation (Inoue and Thomas, 2000) to create strain UA266 [baIn48 $\left(\mathrm{P}_{\text {dat }-1}:\right.$ : $r t c b-1 ; \mathrm{P}_{\text {unc-54 }}:: m$ Cherry); baIn11]. The isolated homozygous integrated line was used for neuroprotection analysis in Figure 1A. UA266 was further crossed into strain UA197 to generate UA267 [baIn48; baIn11; sid-1 (pk3321); uIS69], which was used for neuroprotection analysis in Figure 4A. sid-1 (pk3321) homozygosity was maintained as described previously (Harrington et al., 2012). This strain expresses $\alpha$-syn, GFP, and RTCB-1 in the dopaminergic neurons and is highly selective for RNAi in the neurons.

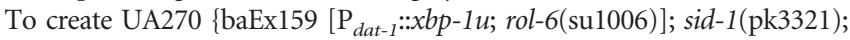
uIS69; baIn11 $\}$, analyzed in Figure $4 B, \mathrm{P}_{\text {dat- } 1}:: x b p$ - $1 u$ and pRF4 rol-6(su1006) were injected into UA197. Strain UA269, analyzed in Figure 5, consists of $\left\{\right.$ baEx158 $\left[\mathrm{P}_{\text {dat }-1}::\right.$ rtcb-1(C122A), rol-6(su1006) $] ;$ baIn11 $\}$.

RNAi treatments. Bacterial RNAi feeding constructs of $r t c b-1$ and $x b p-1$ were obtained from the Ahringer C. elegans library (Kamath et al., 2003); they were isolated and grown overnight in Luria broth media containing $100 \mu \mathrm{g} / \mathrm{ml}$ ampicillin. Nematode growth medium (NGM) plates containing $0.25 \% \beta$-D-lactose were seeded with $250 \mu \mathrm{l}$ of RNAi culture and allowed to dry overnight. Ten dauer or L1-stage worms [N2, or neuron-specific RNAi worm strains (UA196, UA197, UA266 or UA267, UA270] were transferred to the plates and grown at $20^{\circ} \mathrm{C}$ until adulthood. Adult worms were then transferred to corresponding freshly made RNAi plates and allowed to lay eggs for $6 \mathrm{~h}$ to synchronize. For neurodegeneration assays, the DA neurons in the F1 progeny of the RNAitreated worms were scored at days 4, 6, 7 or day 10 after hatching, as described below. For quantitative PCR (qPCR) studies, RNAi-treated late L4 (larval stage) N2 and/or UA202 worms were treated with $10 \mu \mathrm{g} / \mathrm{ml}$ tunicamycin for $6 \mathrm{~h}$ and then collected for RNA isolation, as described below.

C. elegans neurodegeneration assay. Worms were analyzed for DA neurodegeneration as described previously (Cao et al., 2005). Briefly, worms (strains UA196, UA197, UA266, or UA267) were synchronized, grown at $20^{\circ} \mathrm{C}$, and scored for $\alpha$-syn-induced DA neurodegeneration at days 4,6 , 7 or day 10 after hatching. Worms were considered normal when all six anterior DA neurons [four CEP (cephalic) and two ADE (anterior deirid)] were present without any visible signs of degeneration. If a worm displayed degeneration in at least one of the six neurons, it was scored as exhibiting degeneration. In total, at least 90 adult worms were analyzed for each independent transgenic line or RNAi treatment. 6-Hydroxydopamine (6-OHDA) assay was performed as described previously (Nass et al., 2002). Briefly, L4 worms (UA202) were washed with $\mathrm{ddH}_{2} \mathrm{O}$ three times and treated with $30 \mathrm{~mm}$ 6-OHDA (Tocris Bioscience) containing $1 \mathrm{~mm}$ ascorbic acid, followed by gentle agitation for $1 \mathrm{~h}$. Subsequently, the worms were again washed and put onto freshly made RNAi plates until analysis.

$R N A$ isolation from $\mathrm{C}$. elegans. For each independent sample, total RNA was isolated from 50 young adult hermaphrodite worms as described previously (Hamamichi et al., 2008). Briefly, the worms were washed three times with $\mathrm{M} 9$ buffer $\left(3 \mathrm{~g}\right.$ of $\mathrm{KH}_{2} \mathrm{PO}_{4}, 12.8 \mathrm{~g}$ of $\mathrm{Na}_{2} \mathrm{HPO}_{4}$, $5 \mathrm{~g}$ of NaCl, $1 \mathrm{ml}$ of $1 \mathrm{M} \mathrm{MgSO}_{4}$, and $\mathrm{H}_{2} \mathrm{O}$ to $1 \mathrm{~L}$ ) and then frozen at $-80^{\circ} \mathrm{C}$ until use. After thawing, $500 \mu \mathrm{l}$ of TRI Reagent (Molecular Research Center) was added to the samples, followed by brief vortex and incubated at room temperature (RT) for $10 \mathrm{~min}$. The samples were then subjected to repeated freeze-thaw cycling for four times in liquid $\mathrm{N}_{2}$. The phases were separated by adding $50 \mu \mathrm{l}$ of 1-bromo-3-chloropropane (Acros Organics) with $15 \mathrm{~s}$ of vortexing. The samples were then incubated at RT for $15 \mathrm{~min}$ and centrifuged at $13,000 \times g$ at $4^{\circ} \mathrm{C}$ for $15 \mathrm{~min}$. The supernatant was then transferred to an RNase-free microcentrifuge tube, mixed with $1.5 \mu \mathrm{l}$ of glycoblue (Ambion) and $250 \mu \mathrm{l}$ of $-20^{\circ} \mathrm{C}$ chilled isopropanol, and then stored overnight at $-20^{\circ} \mathrm{C}$. After incubation, the sample was centrifuged at $13,000 \times g$ at $4^{\circ} \mathrm{C}$ for $15 \mathrm{~min}$, and the supernatant was discarded. The pellet was washed with $500 \mu$ l of RNasefree ethanol (75\%), air dried for $5 \mathrm{~min}$, and resuspended in $10 \mu \mathrm{l}$ of nuclease-free water. Samples were then treated with $1 \mu \mathrm{l}$ of DNase I and $1 \mu \mathrm{l}$ of DNase I buffer (Promega) at $37^{\circ} \mathrm{C}$ for $15 \mathrm{~min}$ and then for $10 \mathrm{~min}$ with $1 \mu \mathrm{l}$ of DNase stop at $65^{\circ} \mathrm{C}$. Total RNA was quantitated using a Nanodrop and cDNA was synthesized using iScript cDNA synthesis kit (Bio-Rad) following the protocols of the manufacturer.

Real-time qPCR. qPCR reactions were performed using IQ SYBR Green Supermix (Bio-Rad) with the CFX96 Real-Time System (Bio-Rad) as described previously (Thompson et al., 2014). The following previously described primer sequences were used: spliced $x b p-1$, total $x b p-1$, and $h s p-4$ (Richardson et al., 2010); and tba-1, ama-1, and gpd-2 (Hoogewijs et al., 2008). For the remaining primers, full-length gene sequences were obtained from WormBase, and primers were designed by the Primer3 software and evaluated for potential secondary structures of the amplicon by MFOLD software. MFOLD analysis was performed by adjusting the values to $50 \mathrm{~mm}$ $\mathrm{Na}^{+}, 3 \mathrm{~mm} \mathrm{Mg}{ }^{2+}$, and $60^{\circ} \mathrm{C}$ annealing temperature.

The following C. elegans primers were used: spliced $x b p-1$ forward, TGCCTTTGAATCAGCAGTGG; spliced $x b p-1$ reverse, ACCGTCTGCTCCTTCCTCAATG; unspliced $x b p-1$ forward, AGAAGTCGTCGGTGAGGTTG; unspliced $x b p-1$ reverse, CCTGTTCCCACTGCTGAG; total $x b p-1$ forward, CCGATCCACCTCCATCAAC; total $x b p-1$ reverse, ACCGTCTGCTCCTTCCTCAATG; $h s p-4$ forward, AGTTGAAATCATCGCCAACG; $h s p-4$ reverse, GCCCAATCAGACGCTTGG; $r t c b-1$ forward, GGAAGTCGAGGACTTGGACA; $r t c b-1$ reverse, GTTAACCCAGGCGAAGTTTG; $t b a-1$ forward, GTACACTCCACTGATCTCTGCTGACAAG; $t b a-1$ reverse, CTCTGTACAAGAGGCAAACAGCCAT G; ama-1 forward, CCTACGATGTATCGAGGCAAA; ama-1 reverse, CCTCCCTCCGGTGTAATAATG; $g p d-2$ forward, CTCCATCGACTA- 
CATGGTCTACTTG; $g p d$-2 reverse, AGCTGG GTCTCTTGAGTTGTAGAC.

PCR efficiency was calculated from standard curves that were generated using serial dilutions of cDNA of all samples. All targeted genes were measured in triplicate, and three independent biological replicates were tested for each sample. No amplification was detected in no template and no reverse transcriptase controls. The Cq quantification cycle values recorded by CFX Manager Software version 3.0 (Bio-Rad) were exported into qBase ${ }^{\text {PLUS }}$ version 2.6 (Biogazelle) for determining reference target stability (GeNorm $\mathrm{M}<0.5$, CV $<0.2$ ). $a m a-1, t b a-1$, and $g p d-2$ were used as internal controls. Relative mRNA expression levels were normalized using these reference control genes.

Tunicamycin treatment of hsp-4::GFP worms. RNAi-treated [empty vector (EV), $r t c b-1$ or $x b p-1]$ late L4-stage animals were transferred to NGM plates spread with gradient concentrations of tunicamycin: $0,2,4,8,12$, and 16 $\mu \mathrm{g} / \mathrm{ml}$ for an exposure time of $6 \mathrm{~h}$, followed by hsp-4::GFP analysis, as described in the next section. Tunicamycin (Calbiochem) was made at a stock concentration of $1 \mathrm{mg} / \mathrm{ml}$ in DMSO.

Imaging and statistics. Fluorescent microscopy was performed using a Nikon Eclipse E800 epifluorescence microscope equipped with an Endow GFP or Texas Red HYQ filter cube (Chroma Technology). A Cool Snap CCD camera (Photometrics) driven by MetaMorph software (Molecular Devices) was used to acquire images. Using established methods for hsp-4::GFP transcriptional fusion reporter analysis (Chen et al., 2010), each animal was imaged in a consistent anatomical region (at the intestinal region directly behind the pharynx) at the same magnification and exposure intensity. The pixel intensity was quantified within a $100 \times 100 \mu \mathrm{m}$ box drawn in the same region and compiled across three replicates. For statistical analyses of all the datasets, either a Student's $t$ test or one-way ANOVA followed by a Tukey's post hoc was used.

\section{Results}

RTCB-1 rescues age-dependent DA neuron loss induced by $\alpha$-syn overexpression in C. elegans

Previously, a large RNAi screen revealed that depletion of $r t c b-1$ caused enhanced $\alpha$-syn misfolding in $C$. elegans body wall muscle cells (Hamamichi et al., 2008). Alignment of amino acid sequences between metazoan RtcB orthologs reveals the strongly conserved nature of these proteins (Popow et al., 2011). A sequence alignment of human HSPC117 with C. elegans RTCB-1 shows $73 \%$ amino acid sequence identity.

We wanted to determine whether RTCB-1 would protect DA neurons from age-dependent decline from $\alpha$-syn-induced neurodegeneration. Transgenic animals expressing C. elegans $r t c b-1$ cDNA under the control of DA neuron-specific promoter $\left(\mathrm{P}_{\text {dat }-1}:: r t c b-1\right)$ were injected into worms expressing both $\alpha$-syn and GFP in DA
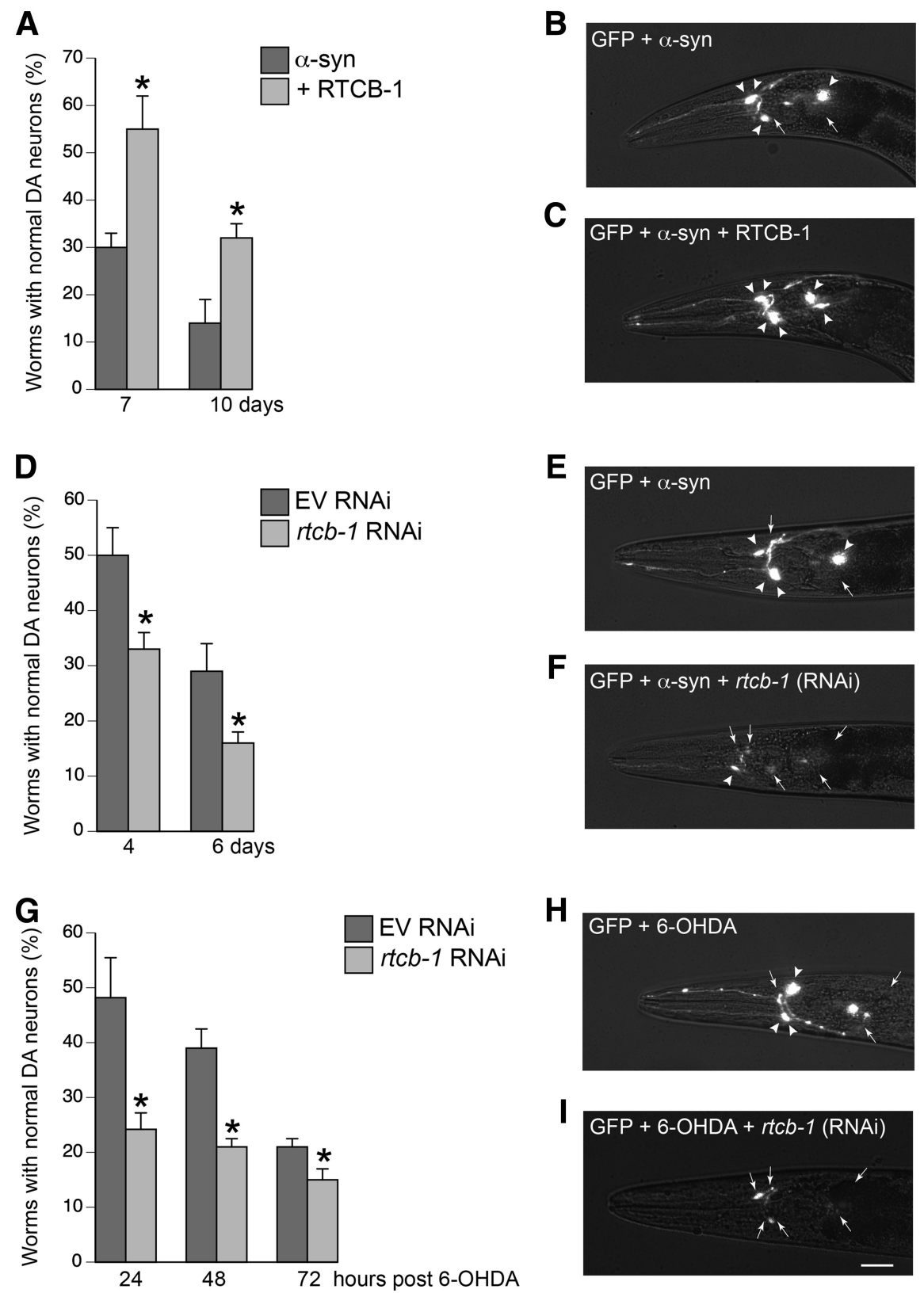

Figure 1. RTCB-1 is neuroprotective against $\alpha$-syn or 6-0HDA-induced toxicity. $A$, RTCB-1 overexpression protects C. elegans DA neurons from $\alpha$-syn-induced neurodegeneration at 7- and 10-d worm stages compared with the $\alpha$-syn control. B, C, Representative images of the neuroprotection assay described in $\boldsymbol{A}$. $\boldsymbol{B}$, Worm expressing GFP and $\alpha$-syn specifically in the six anterior DA neurons with four neurons intact (arrowheads) and two neurons degenerated (arrows). $C$, Worm coexpressing RTCB-1 shows neuroprotection with all six neurons protected (arrowheads). $\boldsymbol{D}$, RNAi depletion of $r t c b$ - 1 enhances DA neurodegeneration caused by $\alpha$-syn at 4 and $6 \mathrm{~d}$ worm stages when compared with $\mathrm{EV} \alpha$-syn control. $\boldsymbol{E}, \boldsymbol{F}$, Representative worm images of the RNAi experiment described in $\boldsymbol{D}$. $\boldsymbol{E}$, Representative RNAi-treated (EV) worm expressing $\alpha$-syn missing two neurons (arrows). $\boldsymbol{F}$, RNAi knockdown of $r t c b-1$ shows increased degeneration with loss of all five of six anterior DA neurons (arrows). G, RNAi depletion of $r t c b-1$ accelerates DA neurodegeneration caused by 6-OHDA at 24, 48, and $72 \mathrm{~h}$ after $1 \mathrm{~h} 6$ 6-OHDA treatment when compared with 6-OHDA-treated EV control. $\boldsymbol{H}$, Exemplar worm exposed to 6-OHDA, in this case missing three DA neurons (arrows). I, A worm treated with rtcb-1 RNAi and 6-OHDA is missing all six neurons, indicative of enhanced degeneration (arrows). Data are reported as the mean $\pm S D, n=30$ worms per trial for a total of three replicates. ${ }^{*} p<0.05$, Student's t test. Scale bar, $20 \mu \mathrm{m}$.

neurons. Overexpression of $\alpha$-syn alone resulted in significant degeneration of DA neurons whereby only 30 and $14 \%$ of the population displayed normal neurons at day 7 and day 10 of the worm lifespan, respectively, indicating an age-dependent degeneration, as reported previously (Hamamichi et al., 2008). Animals coexpressing RTCB- 1 and $\alpha$-syn exhibited significant rescue of DA neurodegeneration at both time points (Fig. 1A). Representative im- 

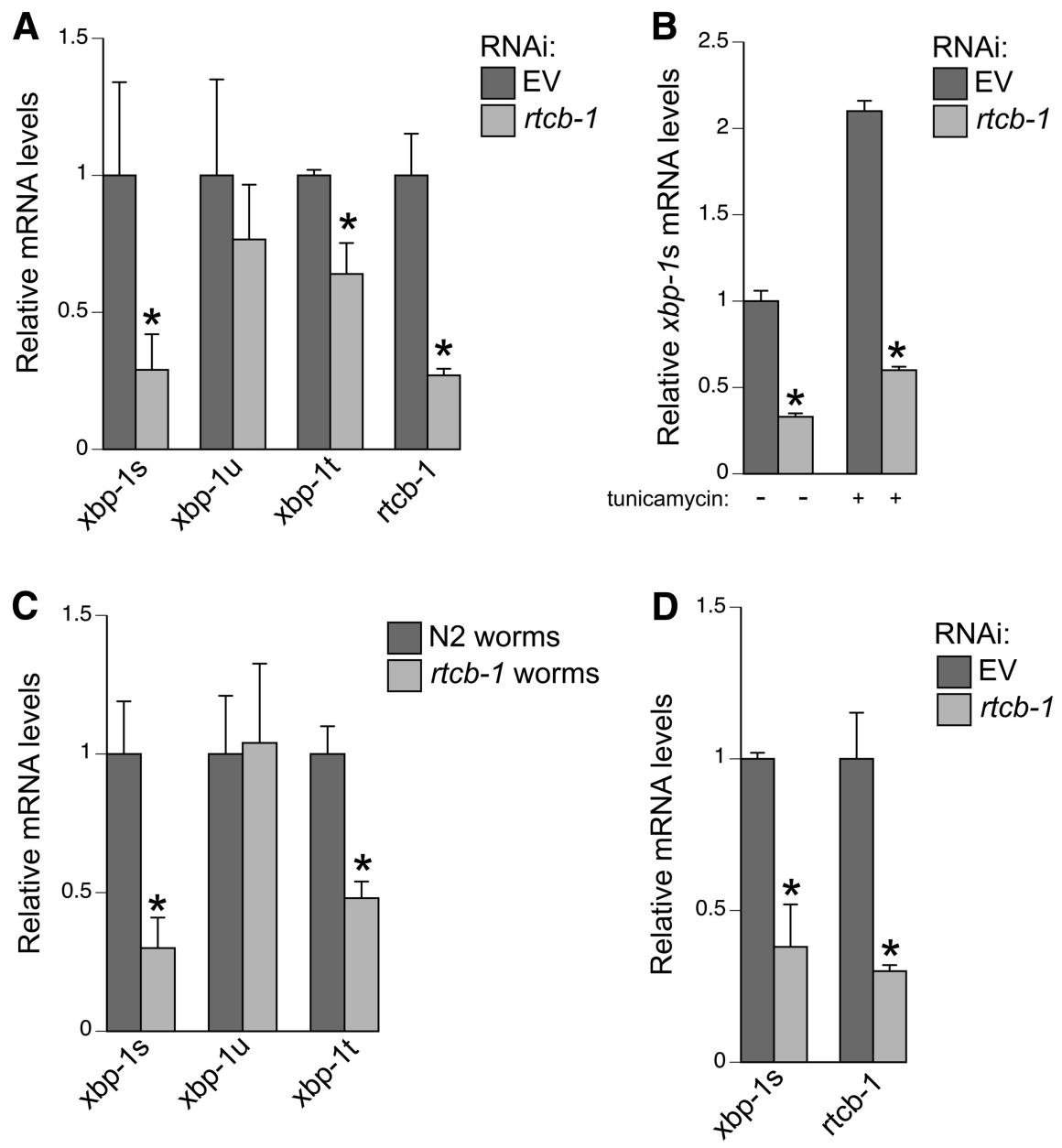

Figure 2. RTCB-1 regulates $x b p-1$ splicing in C. elegans. qPCR-based detection of $x b p-1 \mathrm{~s}, x b p-1 \mathrm{u}, x b p-1 \mathrm{t}$, or $r t c b-1 \mathrm{mRNA}$ expression in RNAi-treated and mutant worm strains. $\boldsymbol{A}$, Tunicamycin (10 $\mu \mathrm{g} / \mathrm{ml})$-treated N2 worms depleted for $r t c b-1$ RNAi display suppressed spliced and total levels of $x b p-1$ when compared with EV control. The unspliced levels of $x b p-1$ are similar in both RNAi treatments. Primers specific to $r t c b$ - 1 were used to confirm knockdown. $\boldsymbol{B}$, A comparison of spliced $x b p-1$ mRNA levels in RNAi-treated N2 worms in the absence and presence of tunicamycin exposure. $\boldsymbol{C}$, Likewise, heterozygous rtcb-1 mutant worms (strain VC1094) treated with tunicamycin showed a significant decrease in $x b p$ - $7 \mathrm{~s}$ and $x b p-1 \mathrm{t}$ when compared with N2 WT worms. D, DA neuron-specific RNAi knockdown of $r t c b-1$ also significantly decreased $x b p$ - 1 s levels in worms (strain UA202) treated with tunicamycin. We confirmed specific knockdown using primers specific to rtcb-1. Relative mRNA expression levels were normalized to the control. Error bars represent \pm SD from three different experiments. ${ }^{*} p<0.05$, Student's t test.

ages depict the neuroprotective effect conferred by RTCB-1 in vivo (Fig. $1 B$ vs $C$ ).

\section{DA neuronal-specific depletion of}

$r t c b$ - 1 enhanced $\alpha$-syn- and 6-OHDA-induced degeneration

As might be expected for a ubiquitous gene product associated with critical cellular processes, a putative C. elegans $r t c b-1$ homozygous null mutant causes sterility. Therefore, to further investigate the neuroprotective properties of RTCB-1, we used a method of neuron-selective RNAi knockdown specifically in DA neurons of C. elegans to assay for neurodegeneration using a DA neuronal-specific RNAi strain expressing $\alpha$-syn and GFP in the DA neurons (Harrington et al., 2012). Loss of RTCB-1 further enhanced DA degeneration caused by $\alpha$-syn at day 4 and day 6 post hatching, when compared to RNAi EV control (Fig. 1D). Figure 1, E and $F$, shows representative images of an RNAi-treated worm expressing $\alpha$-syn and GFP in the DA neurons (EV control) and an $r t c b-1$ RNAi-treated worm expressing $\alpha$-syn and GFP, exhibiting enhanced DA degeneration.
To determine whether the neuroprotective effect of RTCB-1 was specific to $\alpha$-syn, we examined vulnerability to a neurotoxin, 6-OHDA, in worms. Selective degeneration of DA neurons occurs in C. elegans after exposure to 6-OHDA (Nass et al., 2002). Using another DA neuronal-specific RNAi-sensitive strain, expressing only GFP in DA neurons, worms were knocked down with dsRNA targeting $r t c b-1$ or $\mathrm{EV}$ and subjected to 6-OHDA treatment. Animals treated with 6-OHDA and EV RNAi exhibited degeneration of DA neurons at 24, 48, and $72 \mathrm{~h}$ after exposure (Fig. 1G). Cotreatment with $r t c b$ - 1 RNAi caused additional enhancement in DA degeneration at all time points evaluated (Fig. 1G). Representative images of $C$. elegans DA neurons as a result of 6-OHDA exposure with EV or $r t c b-1$ RNAi treatment are shown in Figure $1, H$ and $I$.

\section{RTCB-1 is required for $x b p-1$ mRNA splicing}

According to a recent study in Saccharomyces cerevisiae, the bacterial homolog $\mathrm{RtcB}$ acts as an RNA repair enzyme and has the capacity to replace the function of Trl1 (yeast RNA ligase) as a catalyst of unconventional HAC1 mRNA splicing during the UPR (Tanaka et al., 2011). Similar unconventional splicing has also been described for the gene XBP1 in humans, mice, C. elegans, and Drosophila melanogaster (Hooks and Griffiths-Jones et al., 2011). The unconventional splicing of $X B P 1$ is catalyzed by an endonuclease, IRE1, and an undescribed RNA ligase. Based on these studies, we hypothesized that RTCB-1 could represent the RNA ligase required for $x b p-1$ splicing in C. elegans. Spliced $x b p-1$ level increases in response to tunicamycin in WT (N2) worms, and the level of $x b p-1$ is reduced in $x b p-1$ RNAi worms under both basal and tunicamycin-treated conditions (Chen et al., 2010). To detect a role for RTCB-1 in $x b p-1$ splicing, we performed RNAi knockdown of $r t c b-1$ in N2 worms and measured spliced $(x b p-1 \mathrm{~s})$, unspliced $(x b p-1 \mathrm{u})$, and total $(x b p-1 \mathrm{t}$; i.e., $x b p-1 \mathrm{~s}+x b p-1 \mathrm{u}$ ) levels of $x b p-1$ mRNA, using real-time qPCR. Under tunicamycin-treated conditions, knockdown of $r t c b-1$ significantly lowered $x b p-1 \mathrm{~s}$ and $x b p-1 \mathrm{t}$ mRNA expression compared with control (Fig. 2A). Notably, $x b p$-1u levels were unaffected in RNAi versus control samples. $r t c b-1$ primers were used to ensure its knockdown in these treated worms (Fig. 2A). Under nonstressed (no tunicamycin) conditions, knockdown of $r t c b-1$ also significantly lowers the basal level of $x b p$-1s compared with EV control (Fig. 2B).

We further confirmed these results using an $r t c b-1$ mutant strain, which as a homozygote is sterile and has limited viability; thus, we maintained and analyzed it as a heterozygote. The $r t c b-1$ mutant $g k 451$ consists of a 370 bp deletion spanning the promoter and the first exon, most likely resulting in a nonfunctional 
protein. $r t c b-1$ mutant animals were grown until day 4 after hatching and exposed to tunicamycin (for $6 \mathrm{~h}$ ) along with $\mathrm{N} 2$ control worms. Based on qPCR results, $x b p-1 \mathrm{~s}$ and $x b p-1 \mathrm{t}$ mRNA expression was significantly reduced in $r t c b-1$ mutant worms compared with control animals (Fig. $2 C)$. It should be noted that $x b p-1$ mutant animals, containing a nonsense mutation in the XBP-1 predicted protein, are unable to mount a UPR (Bischof et al., 2008; Chen et al., 2010). These combined RNAi and mutant analyses support the hypothesis that RTCB-1 regulates $x b p-1$ splicing.

We next wanted to determine whether RTCB-1-mediated splicing of $x b p-1$ mRNA was extended to DA neurons. To examine a neuron-specific effect of $x b p-1$ splicing in C. elegans, we used a selectively DA neuronal-sensitive strain to knockdown $r t c b-1$ and measured $x b p-1$ mRNA levels. Using $r t c b$-1-specific primers, we first determined whether the knockdown of $r t c b-1$ in the eight DA neurons of $C$. elegans hermaphrodites could be assessed successfully via qPCR. The results indicated sufficient sensitivity to detect a significant decrease in the expression levels of $r t c b-1$ mRNA in RNAi-treated worms when compared with EV control (Fig. $2 D)$. Furthermore, expression of $x b p-1 s$ was substantially lowered in $r t c b-1$ RNAi worms compared with the control. Therefore, it is clear that RTCB-1 also functions in vivo to mediate $x b p-1$ splicing in DA neurons.

\section{RNAi knockdown of $r t c b-1$ lowers ER stress response in vivo}

In $\mathrm{PD}$, as well as other neurodegenerative diseases, the presence of misfolded proteins disrupts the balance between the synthesis of new proteins and the ability of the ER to process these proteins. As a result, ER stress in turn provokes the UPR, which may protect cells against the toxic accumulation of misfolded proteins (Harding et al., 2002). To examine the function of RTCB-1 during ER stress-induced UPR, an in vivo quantitative readout assay for the ER stress response was performed. Levels of ER stress was monitored in transgenic animals using a fluorescent reporter, GFP, under the control of $h s p-4$ promoter $\left(\mathrm{P}_{h s p-4}:: \mathrm{GFP}\right)$. HSP-4 (worm homolog of $\mathrm{BiP}$ ) is one of the ER chaperones regulated by an active $x b p-1$ (Calfon et al., 2002). During tunicamycin-initiated ER stress, transcription of $h s p-4$ is induced and GFP is highly expressed, thereby providing a direct and quantitative measure of the in vivo stress response. A previous study has shown that $h s p-4:$ GFP worms treated with $x b p-1$ RNAi (in the presence of tunicamycin) exhibit reduced GFP intensity compared with controls (Chen et al., 2010). To determine the role of RTCB-1 in ER stress response, worms fed with $r t c b-1$ RNAi (or $x b p-1$ RNAi as a positive control) were treated using a gradient of tunicamycin concentrations and examined by fluorescent intensity changes. As expected, a signifi- cant decrease in $h s p-4:$ GFP expression was observed for both $x p b-1$ RNAi and $r t b c-1$ RNAi compared with the EV RNAi control at all concentrations tested (Fig. $3 A-C$ ). We also performed qPCR to measure the mRNA expression of $h s p-4$ in these RNAitreated worms that were exposed to $10 \mu \mathrm{g} / \mathrm{ml}$ tunicamycin. Similar to the in vivo results, the levels of $h s p-4$ expression in $r t c b-1$ and $x b p-1$ RNAi worms were lower than that of the EV RNAi treated animals (Fig. 3D). These data further strengthen the genetic link between RTCB-1 activity and $x b p-1$ in regulating ER stress response.

\section{RNAi depletion of $x b p-1$ blocks the neuroprotective function of RTCB-1}

Having revealed a role for RTCB-1 in $x b p-1$ mRNA splicing, we sought to determine whether its neuroprotective function is mediated by XBP-1. In vitro studies in SH-SY5Y cells and in vivo studies in mice have shown that overexpression of $x b p-1 s$ protects 


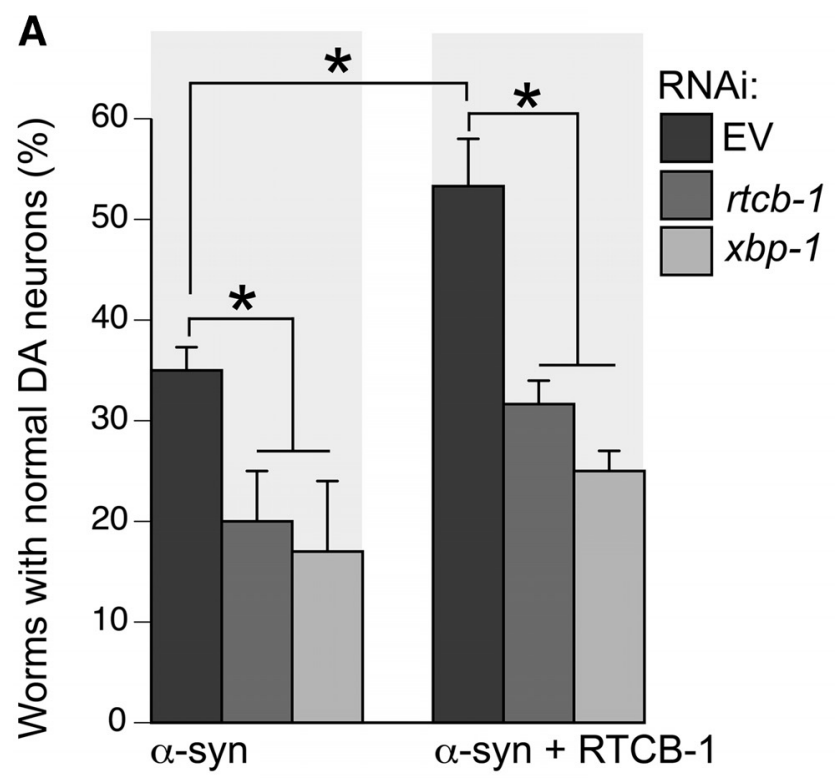

B

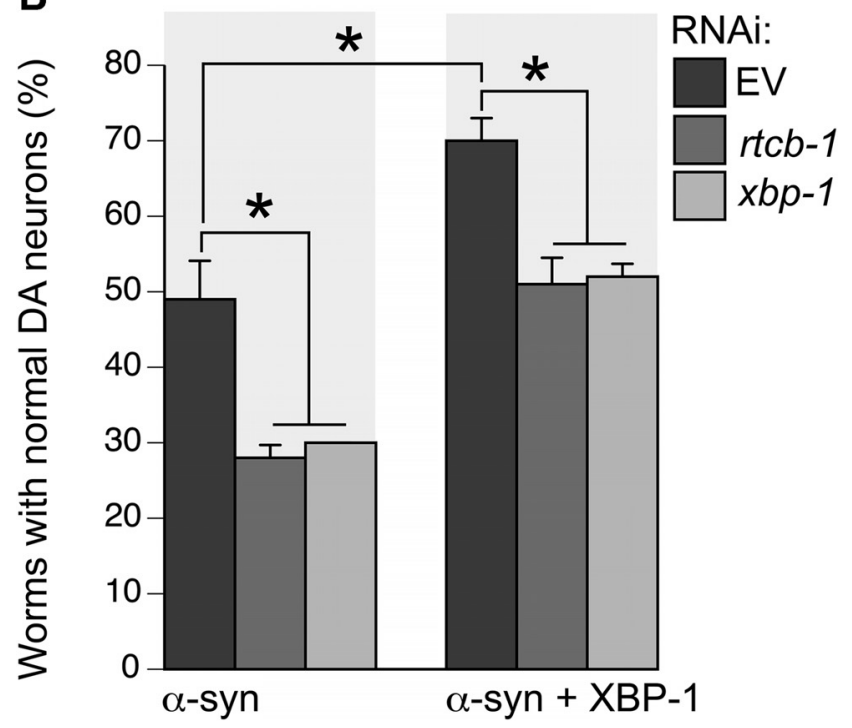

Figure 4. RTCB-1-induced neuroprotection against $\alpha$-syn is mediated by XBP-1 signaling. $A$, Pan-neuronal-specific knockdown of $r t c b$ - 1 or xbp-1 enhances $\alpha$-syn-induced neurodegeneration when compared with the EV control. These worms expressing $\alpha$-syn and GFP were then crossed with worms expressing RTCB-1. Overexpression of RTCB-1 protects DA neurons from $\alpha$-syn-induced toxicity in worms treated with RNAi EV. RNAi knockdown of $r t c b-1$ or $x b p-1$ failed to protect neurons from $\alpha$-syn-induced degeneration in an RTCB-1 overexpression background. $\boldsymbol{B}, 0$ verexpression of XBP-1 protects DA neurons from $\alpha$-syn-induced toxicity in worms treated with RNAiEV when compared with $\alpha$-syn control. Pan-neuronal-specific knockdown of $r t c b-1$ blocks the neuroprotective phenotype of XBP-1. DA neuron analyses were performed at day 6 after hatching. Data are reported as the mean $\pm S D, n=30$ worms per trial for a total of three replicates. ${ }^{*} p<0.05$, one-way ANOVA.

DA neurons from dying from MPTP (Sado et al., 2009). Here we used a pan-neuronal-sensitive RNAi strain expressing $\alpha$-syn and GFP in DA neurons to perform RNAi knockdown of $x b p-1$ and $r t c b-1$ separately. Strikingly, we observed a significant change in neurodegeneration in each of them compared with the $\alpha$-syn control (Fig. 4A). To examine the genetic interaction between RTCB- 1 and $x b p-1$ in regulating neuroprotection, we crossed our pan-neuronal-specific RNAi strain (expressing $\alpha$-syn and GFP in DA neurons) with worms overexpressing RTCB-1 in DA neurons $\left(\mathrm{P}_{\text {dat- } 1}: \because t c b-1\right)$ to generate a pan-neuronal-selective RNAi- sensitive strain expressing $\alpha$-syn, RTCB-1, and GFP in DA neurons. Analysis of this new strain showed that RTCB-1 overexpression attenuated the DA neuron loss induced by $\alpha$-syn, consistent with our previous results using a non-RNAi-specific strain (Fig. 4A). By using this strain for RNAi analysis, we further discerned that $x b p-1$ knockdown suppressed the neuroprotective phenotype attained through RTCB-1 overexpression (Fig. 4A). Thus, RTCB-1-mediated neuroprotection requires XBP-1.

To further support this conclusion, we overexpressed XBP-1 in DA neurons of worms expressing $\alpha$-syn and observed significant neuroprotection with the endogenous level of $r t c b-1$ (Fig. 4B). Alternately, knocking down $r t c b-1$ in this XBP-1 overexpression background caused a reversal of the neuroprotective phenotype (Fig. $4 B$ ); this was anticipated, because loss of $r t c b-1$ would block the splicing of $x b p-1$ mRNA (as already shown in Fig. 2). Together, these results suggest that RTCB-1-induced neuroprotection is mediated through XBP-1 signaling. Whereas loss of $x b p-1$ negates the neuroprotective phenotype of RTCB-1, loss of $r t c b-1$ blocks the neuroprotective phenotype of XBP-1 on $\alpha$-syninduced degeneration.

\section{Mutation of a conserved residue abolishes neuroprotective activity of RTCB-1}

Previously, it has been shown that mutation of a conserved residue (C122A) in the human RTCB-1 homolog HSPC117 abolished its RNA ligase activity (Popow et al., 2011). To investigate whether putative RNA ligase activity of RTCB-1 is required for its neuroprotection, we created a ligase-dead version of $C$. elegans RTCB- 1 by mutating the same site in the worm homolog, which contains a conserved residue at the same amino acid position $\left(\mathrm{Cys}^{122}\right.$ to $\left.\mathrm{Ala}^{122}\right)$. The $r t c b-1(\mathrm{C} 122 \mathrm{~A})$ variant was overexpressed in DA neurons of worms also expressing $\alpha$-syn. Unlike WT $r t c b-1$, this mutated version was unable to provide significant neuroprotection when compared with $\alpha$-syn alone as worms aged (compare Figs. 5 and 1).

\section{Discussion}

Humans, bacteria, and archaea all have RTCB-1 homologs, thus showing the evolutionary conservation of this protein. These proteins are characterized to be novel RNA ligases implicated in tRNA splicing and repair (Englert et al., 2011; Popow et al., 2011; Tanaka et al., 2011; Chakravarty et al., 2012). However, with the exception of the C. elegans ortholog, these proteins have not been correlated directly with neuronal function or survival to date. In the study by Kanai et al. (2004), the human homolog HSPC117 was identified to be a component of RNA transporting granule, thereby suggesting an overall role in RNA processing or RNA metabolism. The high degree of conservation among RtcB proteins suggests a shared function for C. elegans RTCB-1 with other family members. In this context, we determined that RTCB-1, a previously uncharacterized protein in C. elegans, is a neuroprotective gene product that regulates $x b p-1$ mRNA splicing in vivo. Likewise, it is evident that the underlying mechanism associated with RTCB-1-mediated neuroprotection is based on XBP-1mediated UPR signaling.

Conventional splicing is catalyzed by the spliceosome and takes place exclusively in the nucleus (Tarn and Steitz, 1997). In contrast, the unconventional splicing of $H A C 1$ and $X B P 1$ is mechanistically distinct and is completely independent of the spliceosome in that it is catalyzed by IRE1 endonuclease and an RNA ligase (Sidrauski et al., 1996; Kawahara et al., 1998; Gonzalez et al., 1999; Yoshida et al., 2001). Furthermore, unconventional splicing of yeast $H A C 1$ and XBP1 mRNAs occurs in the 


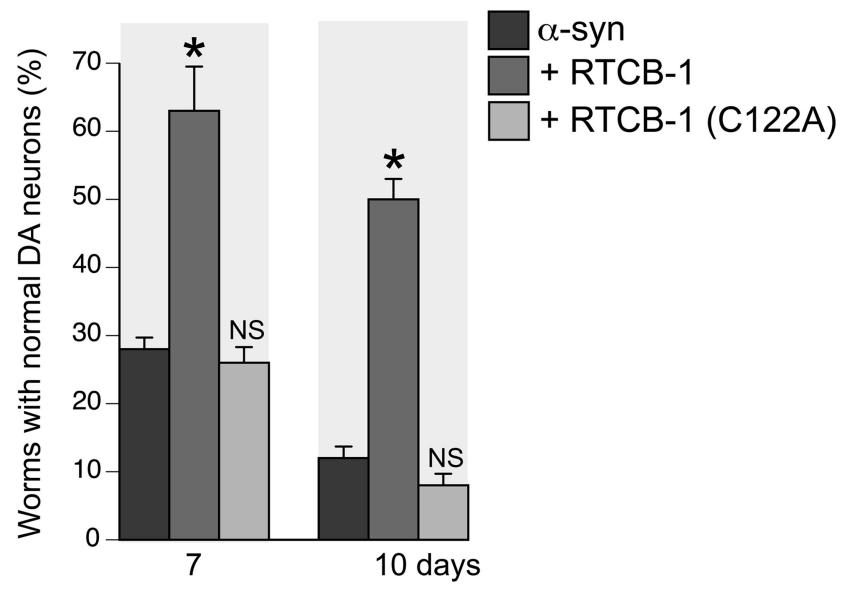

Figure 5. Overexpression of $r t c b-1$ (C122A) in DA neurons is not protective from $\alpha$-syninduced neurodegeneration. Analysis of worm RTCB-1 mutant at days 7 and 10 failed to show any significant protection of DA neurons when compared with $\alpha$-syn control, yet overexpression of WT RTCB-1 was protective.

cytoplasm during the UPR (Ruegsegger et al., 2001; Uemura et al., 2009). Notably, there are no RtcB homologs in yeast or plants, but bacterial RtcB can complement the function of yeast tRNA ligase in HAC1 mRNA splicing (Tanaka et al., 2011).

In mammals, along with the conserved IRE1 signaling pathway, two additional UPR pathways have evolved to maintain proteostasis. These two pathways are respectively mediated by pancreatic-enriched ER kinase (PERK), which facilitates translational inhibition to reduce protein production, and activating transcription factor 6 (ATF6), which mediates transcription to increase the levels of chaperone proteins (Haze et al., 1999; Sood et al., 2000). The coordination of these three pathways provides protection against ER stress in mammals. C. elegans has homologs of the vertebrate UPR components IRE1, ATF6, and PERK (Shen et al., 2001; Urano et al., 2002). It also retains the essential function of these components in upregulating the expression of UPR target genes during ER stress. Worms treated with ER stress inducers, such as tunicamycin, thapsigargin, or DTT, exhibit an increase of spliced or stressed $x b p-1$ ( $x b p-1 s)$, followed by activation of UPR genes involved in ER biogenesis (Shen et al., 2001; Calfon et al., 2002). The requirement for the UPR pathway in C. elegans is cell type and age dependent, and expression of XBP-1 is elevated in neurons during development (Hetz et al., 2008). Studies have shown that C. elegans XBP-1 functions in the nervous system and loss of $x b p-1$ blocks UPR signaling (Calfon et al., 2002). Therefore, our data showing the neuroprotective function of RTCB-1 and its role in regulation of UPR $x b p-1$ splicing further strengthens our conclusions. For additional studies, it will be instructive to determine a putative neuronal role of RTCB-1 in mitochondrial stress response, because both the ER and mitochondria coordinate the UPR.

Misfolded proteins and associated ER stress are common features of neurodegenerative diseases. Overexpression of mutant forms of $\alpha$-syn in cultured neuronal cells leads to proteasomal dysfunction and DA neurodegeneration (Stefanis et al., 2001; Tanaka et al., 2001). We reported previously that $\alpha$-syn aggregation impairs vesicle trafficking and degradation of selective ERAD substrates and causes ER stress (Cooper et al., 2006). Neurotoxins, such as 6-OHDA and MPTP, also cause dopaminergic neuronal death and trigger the activation of genes involved in ER stress and the UPR (Ryu et al., 2002; Holtz and O’Malley, 2003). Inactivation of the UPR leads to organelle dysfunction and cell

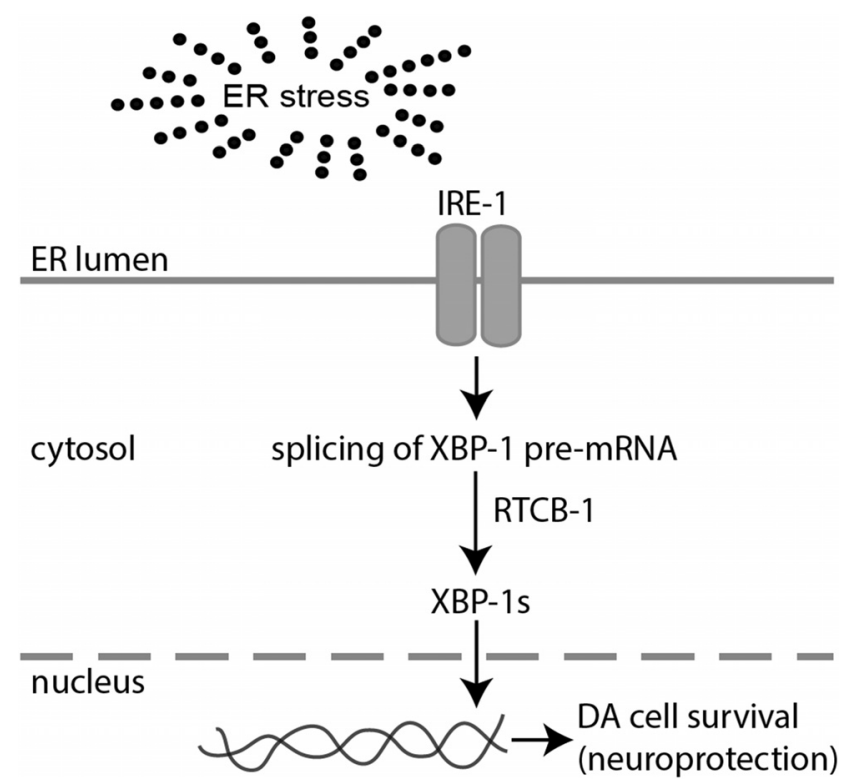

Figure 6. Proposed model for RTCB-1-mediated DA neuroprotection in C. elegans. This tentative model describes our current understanding of the underlying mechanism involved in RTCB-1-induced neuroprotection against DA neuron cell death caused by various stressors. We have determined previously that RTCB-1 protects cells from $\alpha$-syn protein misfolding or $\alpha$-syninduced neuronal toxicity. It is possible that, during ER stress caused by accumulation of such toxic misfolded or unwanted proteins, RTCB-1 acts as an RNA modifier that regulates the splicing of the XBP-1 transcription factor in UPR. This in turn activates downstream factors, such as ER chaperones and the hexosamine biosynthetic pathway, and stimulates cytoprotective mechanisms to reestablish protein homeostasis (Denzel et al., 2014). In our C. elegans PD model, cells depleted with rtcb-1 might block the UPR pathway because of a failure in $x b p-1$ splicing, leading to cell death or DA neuronal death caused by ER overload. Alternatively, overexpression of RTCB-1 might lead to prolonged xbp-1 splicing, thereby enhancing proteostasis activity, maintaining ER stress response, and thus protecting against neuronal damage caused by $\alpha$-syn. Based on our neurodegeneration and splicing assay, the association between RTCB-1 and XBP-1 could be direct or indirect in the regulation of the UPR pathway.

death. For example, deletion of PERK impairs cell survival, whereas increased PERK activity is protective (Harding et al., 2000; Scheuner et al., 2001; Lu et al., 2004). Similarly, IRE1-XBP1 signaling has a protective role during ER stress. In vitro ectopic expression of XBP1s activated various secretory pathway genes, increased cell size, and elevated total protein synthesis (Shaffer et al., 2004). XBP-1 also plays a role in controlling the autophagic clearance of aggregated proteins (Hetz et al., 2009). A recent study reported that silencing of XBP1 in mice led to ER stress and DA neurodegeneration, indicating the functional requirement of the UPR in maintaining neuronal proteostasis (Valdés et al., 2014). In addition, overexpression of XBP1 has been shown to be protective against proteasome inhibition- or ischemic-induced cell death in neuronal cells (Sado et al., 2009; Ibuki et al., 2012). Likewise, in our C. elegans model for $\alpha$-syn-induced DA neurodegeneration, we demonstrated that overexpression of XBP-1 is neuroprotective, whereas neuron-specific RNAi knockdown of $x b p-1$ exacerbated the neurodegeneration.

These previous discoveries highlight the importance of identifying mediators of $x b p-1$ activity, which take on added significance when considering neurodegeneration. Here we have shown that overexpression of RTCB-1 in DA neurons of worms expressing $\alpha$-syn attenuated degenerating neurons from $\alpha$-syninduced toxicity, whereas neuron-specific depletion of $x b p-1$ loses the protective function of RTCB- 1 in the same strain of worms coexpressing RTCB- 1 and $\alpha$-syn in DA neurons. Similarly, we also showed that neuron-selective knockdown of $r t c b-1$ 
attenuates the neuroprotective phenotype of XBP-1 in worms expressing $\alpha$-syn. These results uncover a functional relationship between RTCB-1 and XBP-1 in regulating neuroprotection against proteostatic stress caused by $\alpha$-syn (Fig. 6). For the road ahead, an important goal is to explore the transcriptional status of RTCB- 1 and XBP- 1 in $\alpha$-syn transgenic worms. Using qPCR and transgenic worms overexpressing $\alpha$-syn in the nematode body wall muscles (Hamamichi et al., 2008), we have discerned that $r t c b-1$ is not regulated by $\alpha$-syn (data not shown). However, it is yet to be determined whether $\alpha$-syn induces transcriptional activation of $x b p-1$. In vitro studies showed that $\alpha$-syn oligomers induce $x b p-1$ splicing (Castillo-Carranza et al., 2012), indicating that $\alpha$-syn is an ER stressor. In vivo studies have also shown that XBP-1 significantly reduces $\alpha$-syn levels (Si et al., 2012). Pathologically, our results support the idea that RTCB-1-induced activation of XBP-1 promotes clearance of abnormally accumulated $\alpha$-syn and thus plays a neuroprotective role. Thus, identification of the signals modulating this cellular response may contribute to the treatment of PD.

Previously, an ER chaperone, Hsp70, was shown to inhibit $\alpha$-syn-induced toxicity in a Drosophila PD model (Auluck et al., 2002). According to another study, mammalian Hsp70 interacts with IRE1, and this interaction prolongs the splicing of $X B P 1$, thereby activating UPR target genes and protecting cells from cell death (Gupta et al., 2010). Likewise, we propose a model in which overexpression of RTCB-1 in C. elegans DA neurons might prolong the splicing of $x b p-1$, thus activating ER chaperone proteins and rescuing $\alpha$-syn-induced neurodegeneration (Fig. 6), whereas cells depleted of RTCB-1 would hinder $x b p-1$ splicing, thereby blocking UPR signaling and promoting cell death caused by $\alpha$-syn (Figs. 2, 4). Recently, the mammalian RtcB has been identified as a UPR RNA ligase regulating XBP1 splicing in vitro (Lu et al., 2014). Moreover, cells expressing the ligase-dead RtcB (C122A) exhibited XBP-1 splicing defects. Our findings are consistent with these results in that $C$. elegans RTCB- 1 also regulates XBP-1 splicing in the UPR pathway. We also determined that the ligase-active site of worm RTCB-1 (Cys ${ }^{122}$ ) is necessary for its neuroprotective function. Our findings further extend the understanding of RTCB-1 function in the context of neurodegeneration and as a previously uncharacterized neuroprotective gene product with potential as a therapeutic target.

Growing evidence suggests that proteins functioning in RNA synthesis, processing, splicing, or degradation are mechanistically significant for neurodegenerative disorders (Cooper et al., 2009). Mutations in genes that are involved in RNA metabolism, such as TDP-43 (TAR DNA-binding protein) and FUS (fused in sarcoma, translocated in liposarcoma), have been found to cause motor neuron diseases (Gitcho et al., 2008; Vance et al., 2009). Both of these proteins are implicated in mRNA splicing (Belly et al., 2005; Buratti and Baralle, 2008). Additionally, mutations in tRNA splicing endonuclease (TSEN54) and tRNA synthetase have also been shown to cause motor neurodegeneration (Wan et al., 2012). The neuronal phenotypes caused by mutations in these genes could be a result of RNA processing defects as observed with RTCB-1 studies or could be attributable to alternate biochemical and cellular activities distinct from RNA processing (Antonellis et al., 2003; Jordanova et al., 2006; Latour et al., 2010). Interestingly, a recent $C$. elegans RNAi screen identified RTCB-1 (F16A11.2) as a modifier for GABAergic axonal regeneration (Nix et al., 2014). These and other studies suggest that defects in RNA metabolism (regulated at many different levels) can be pathogenically related to various neurodegenerative disorders. In this regard, an in-depth understanding of the pathways involving
RTCB-1, or its potential functional effectors, might yield promising and unexploited targets for therapeutic development to prevent neurodegeneration.

\section{References}

Antonellis A, Ellsworth RE, Sambuughin N, Puls I, Abel A, Lee-Lin SQ, Jordanova A, Kremensky I, Christodoulou K, Middleton LT, Sivakumar K, Ionasescu V, Funalot B, Vance JM, Goldfarb LG, Fischbeck KH, Green ED (2003) Glycyl tRNA synthetase mutations in Charcot-Marie-Tooth disease type $2 \mathrm{D}$ and distal spinal muscular atrophy type V. Am J Hum Genet 72:1293-1299. CrossRef Medline

Auluck PK, Chan HY, Trojanowski JQ, Lee VMY, Bonini NM (2002) Chaperone suppression of $\alpha$-Synuclein toxicity in a Drosophila model for Parkinson's disease. Science 295:865-868. CrossRef Medline

Belly A, Moreau-Gachelin F, Sadoul R, Goldberg Y (2005) Delocalization of the multifunctional RNA splicing factor TLS/FUS in hippocampal neurons: exclusion from the nucleus and accumulation in dendritic granules and spine heads. Neurosci Lett 379:152-157. CrossRef Medline

Bischof LJ, Kao CY, Los FCO, Gonzalez MR, Shen Z, Briggs SP, van der Goot FG, Aroian RV (2008) Activation of the unfolded protein response is required for defenses against bacterial pore-forming toxin in vivo. PLoS Pathog 4:e1000176. CrossRef Medline

Brenner S (1974) The genetics of Caenorhabditis elegans. Genetics 77:71-94. Medline

Buratti E, Baralle FE (2008) Multiple roles of TDP-43 in gene expression, splicing regulation, and human disease. Front Biosci 13:867-878. CrossRef Medline

Calfon M, Zeng H, Urano F, Till JH, Hubbard SR, Harding HP, Clark SG, Ron D (2002) IRE1 couples endoplasmic reticulum load to secretory capacity by processing the XBP-1 mRNA. Nature 415:92-96. CrossRef Medline

Cao S, Gelwix CC, Caldwell KA, Caldwell GA (2005) Torsin mediated protection from cellular stress in the dopaminergic neurons of Caenorhabditis elegans. J Neurosci 25:3801-3812. CrossRef Medline

Castillo-Carranza DL, Zhang Y, Guerrero-Muñoz MJ, Kayed R, RinconLimas DE, Fernandez-Funez P (2012) Differential activation of the ER stress factor XBP1 by oligomeric assemblies. Neurochem Res 37:17071717. CrossRef Medline

Chakravarty AK, Subbotin R, Chait BT, Shumana S (2012) RNA ligase RtcB splices $3^{\prime}$-phosphate and 5'-OH ends via covalent RtcB-(histidinyl)-GMP and polynucleotide- $\left(3^{\prime}\right) \mathrm{pp}\left(5^{\prime}\right) \mathrm{G}$ intermediates. Proc Natl Acad Sci U S A 109:6072-6077. CrossRef Medline

Chen P, Burdette AJ, Porter JC, Ricketts JC, Fox SA, Nery FC, Hewett JW, Berkowitz LA, Breakefield XO, Caldwell KA, Caldwell GA (2010) The early-onset torsion dystonia-associated protein, torsinA, is a homeostatic regulator of endoplasmic reticulum stress response. Hum Mol Genet 19: 3502-3515. CrossRef Medline

Cooper AA, Gitler AD, Cashikar A, Haynes CM, Hill KJ, Bhullar B, Liu K, Xu K, Strathearn KE, Liu F, Cao S, Caldwell KA, Caldwell GA, Marsischky G, Kolodner RD, Labaer J, Rochet JC, Bonini NM, Lindquist S (2006) $\alpha$-Synuclein blocks ER-Golgi traffic and Rab1 rescues neuron loss in Parkinson's models. Science 313:324-328. CrossRef Medline

Cooper TA, Wan L, Dreyfuss G (2009) RNA and disease. Cell 136:777-793. CrossRef Medline

Denzel MS, Storm NJ, Gutschmidt A, Baddi R, Hinze Y, Jarosch E, Sommer T, Hoppe T, Antebi A (2014) Hexosamine pathway metabolites enhance protein quality control and prolong life. Cell 156:1167-1178. CrossRef Medline

Dickson DW, Braak H, Duda JE, Duyckaerts C, Gasser T, Halliday GM, Hardy J, Leverenz JB, Tredici DK, Wszolek ZK, Litvan I (2009) Neuropathological assessment of Parkinson's disease: refining the diagnostic criteria. Lancet Neurology 8:1150-1157. CrossRef Medline

Englert M, Sheppard K, Aslanian A, Yates JR 3rd, Söll D (2011) Archaeal 3 '-phosphate RNA splicing ligase characterization identifies the missing component in tRNA maturation. Proc Natl Acad Sci U S A 108:12901295. CrossRef Medline

Gitcho MA, Baloh RH, Chakraverty S, Mayo K, Norton JB, Levitch D, Hatanpaa KJ, White CL 3rd, Bigio EH, Caselli R, Baker M, Al-Lozi MT, Morris JC, Pestronk A, Rademakers R, Goate AM, Cairns NJ (2008) TDP-43 A315T mutation in familial motor neuron disease. Ann Neurol 63:535538. CrossRef Medline

Gonzalez TN, Sidrauski C, Dörfler S, Walter P (1999) Mechanism of non- 
spliceosomal mRNA splicing in the unfolded protein response pathway. EMBO J 18:3119-3132. CrossRef Medline

Gupta S, Deepti A, Deegan S, Lisbona F, Hetz C, Samali A (2010) HSP72 protects cells from ER stress-induced apoptosis via enhancement of IRE1 $\alpha$-XBP1 signaling through a physical interaction. PLoS Biol 8:e1000410. CrossRef Medline

Hamamichi S, Rivas RN, Knight AL, Cao S, Caldwell KA, Caldwell GA (2008) Hypothesis-based RNAi screening identifies neuroprotective genes in a Parkinson's disease model. Proc Natl Acad Sci U S A 105:728733. CrossRef Medline

Harding HP, Zhang Y, Bertolotti A, Zeng H, Ron D (2000) Perk is essential for translational regulation and cell survival during the unfolded protein response. Mol Cell 5:897-904. CrossRef Medline

Harding HP, Calfon M, Urano F, Novoa I, Ron D (2002) Transcriptional and translational control in the mammalian unfolded protein response. Annu Rev Cell Dev Biol 18:575-599. CrossRef Medline

Harrington AJ, Yacoubian TA, Slone SR, Caldwell KA, Caldwell GA (2012) Functional analysis of VPS41-mediated neuroprotection in Caenorhabditis elegans and mammalian models of Parkinson's disease. J Neurosci 32:2142-2153. CrossRef Medline

Haze K, Yoshida H, Yanagi H, Yura T, Mori K (1999) Mammalian transcription factor ATF6 is synthesized as a transmembrane protein and activated by proteolysis in response to endoplasmic reticulum stress. Mol Biol Cell 10:3787-3799. CrossRef Medline

Hetz C, Lee AH, Gonzalez-Romero D, Thielen P, Castilla J, Soto C, Glimcher LH (2008) Unfolded protein response transcription factor XBP-1 does not influence prion replication or pathogenesis. Proc Natl Acad Sci U S A 105:757-762. CrossRef Medline

Hetz C, Thielen P, Matus S, Nassif M, Court F, Kiffin R, Martinez G, Cuervo AM, Brown RH, Glimcher LH (2009) XBP-1 deficiency in the nervous system protects against amyotrophic lateral sclerosis by increasing autophagy. Genes Dev 23:2294-2306. CrossRef Medline

Holtz WA, O’Malley KL (2003) Parkinsonian mimetics induce aspects of unfolded protein response in death of dopaminergic neurons. J Biol Chem 278:19367-19377. CrossRef Medline

Hoogewijs D, Houthoofd K, Matthijssens F, Vandesompele J, Vanfleteren JR (2008) Selection and validation of a set of reliable reference genes for quantitative sod gene expression analysis in C. elegans. BMC Mol Biol 9:9. CrossRef Medline

Hooks KB, Griffiths-Jones S (2011) Conserved RNA structures in the noncanonical Hac1/Xbp1 intron. RNA Biol 8:552-556. CrossRef Medline

Ibuki T, Yamasaki Y, Mizuguchi H, Sokabe M (2012) Protective effects of XBP1 against oxygen and glucose deprivation/reoxygenation injury in rat primary hippocampal neurons. Neurosci Lett 518:45-48. CrossRef Medline

Inoue T, Thomas JH (2000) Targets of TGF- $\beta$ Signaling in Caenorhabditis elegans dauer formation. Dev Biol 217:192-204. CrossRef Medline

Iwawaki T, Hosoda A, Okuda T, Kamigori Y, Nomura-Furuwatari C, Kimata Y, Tsuru A, Kohno K (2001) Translational control by the ER transmembrane kinase/ribonuclease IRE1 under ER stress. Nat Cell Biol 3:158-164. CrossRef Medline

Jordanova A, Irobi J, Thomas FP, Dijck PV, Meerschaert K, Dewil M, Dierick I, Jacobs A, De Vriendt E, Guergueltcheva V, Rao CV, Tournev I, Gondim FA, D'Hooghe M, Van Gerwen V, Callaerts P, Van Den Bosch L, Timmermans JP, Robberecht W, Gettemans J, et al. (2006) Disrupted function and axonal distribution of mutant tyrosyl-tRNA synthetase in dominant intermediate Charcot-Marie-Tooth neuropathy. Nat Genet 38:197-202. CrossRef Medline

Kamath RS, Fraser AG, Dong Y, Poulin G, Durbin R, Gotta M, Kanapin A, Le Bot N, Moreno S, Sohrmann M, Welchman DP, Zipperlen P, Ahringer J (2003) Systematic functional analysis of the Caenorhabditis elegans genome using RNAi. Nature 421:231-237. CrossRef Medline

Kanai Y, Dohmae N, Hirokawa N (2004) Isolation and characterization of an RNA-transporting granule. Neuron 43:513-525. CrossRef Medline

Kawahara T, Yanagi H, Yura T, Mori K (1998) Unconventional splicing of HAC1/ERN4 mRNA required for the unfolded protein response. Sequence-specific and non-sequential cleavage of the splice sites. J Biol Chem 273:1802-1807. CrossRef Medline

Latour P, Thauvin-Robinet C, Baudelet-Méry C, Soichot P, Cusin V, Faivre L, Locatelli MC, Mayençon M, Sarcey A, Broussolle E, Camu W, David A, Rousson R (2010) A major determinant for binding and aminoacylation of tRNA(Ala) in cytoplasmic Alanyl-tRNA synthetase is mutated in dom- inant axonal Charcot-Marie-Tooth disease. Am J Hum Genet 86:77-82. CrossRef Medline

Lu PD, Jousse C, Marciniak SJ, Zhang Y, Novoa I, Scheuner D, Kaufman RJ, Ron D, Harding HP (2004) Cytoprotection by pre-emptive conditional phosphorylation of translation initiation factor 2. EMBO J 23:169-179. CrossRef Medline

Lu Y, Liang FX, Wang X (2014) A synthetic biology approach identifies the mammalian UPR RNA ligase RtcB. Mol Cell 55:758-770. CrossRef Medline

Nass R, Hall DH, Miller DM 3rd, Blakely RD (2002) Neurotoxin-induced degeneration of dopamine neurons in Caenorhabditis elegans. Proc Natl Acad Sci U S A 99:3264-3269. CrossRef Medline

Nix P, Hammarlund M, Hauth L, Lachnit M, Jorgensen EM, Bastiani M (2014) Axon regeneration genes identified by RNAi screening in C.elegans. J Neurosci 34:629-645. CrossRef Medline

Popow J, Englert M, Weitzer S, Schleiffer A, Mierzwa B, Mechtler K, Trowitzsch S, Will CL, Lührmann R, Söll D, Martinez J (2011) HSPC117 is the essential subunit of a human tRNA splicing ligase complex. Science 331: 760-764. CrossRef Medline

Richardson CE, Kooistra T, Kim DH (2010) An essential role for XBP-1 in host protection against immune activation in C. elegans. Nature 463: 1092-1095. CrossRef Medline

Rousseau S, Morrice N, Peggie M, Campbell DG, Gaestel M, Cohen P (2002) Inhibition of SAPK2a/p38 prevents hnRNP A0 phosphorylation by MAPKAP-K2 and its interaction with cytokine mRNAs. EMBO J 21: 6505-6514. CrossRef Medline

Rüegsegger U, Leber JH, Walter P (2001) Block of HAC1 mRNA translation by long-range base pairing is released by cytoplasmic splicing upon induction of the unfolded protein response. Cell 107:103-114. CrossRef Medline

Ryu EJ, Harding HP, Angelastro JM, Vitolo OV, Ron D, Greene LA (2002) Endoplasmic reticulum stress and the unfolded protein response in cellular models of Parkinson's disease. J Neurosci 22:10690-10698. Medline

Sado M, Yamasaki Y, Iwanaga T, Onaka Y, Ibuki T, Nishihara S, Mizuguchi H, Momota H, Kishibuchi R, Hashimoto T, Wada D, Kitagawa H, Watanabe TK (2009) Protective effect against Parkinson's disease-related insults through the activation of XBP1. Brain Res 1257:16-24. CrossRef Medline

Scheuner D, Song B, McEwen E, Liu C, Laybutt R, Gillespie P, Saunders T, Bonner-Weir S, Kaufman RJ (2001) Translational control is required for the unfolded protein response and in vivo glucose homeostasis. Mol Cell 7:1165-1176. CrossRef Medline

Shaffer AL, Shapiro-Shelef M, Iwakoshi NN, Lee AH, Qian SB, Zhao H, Yu X, Yang L, Tan BK, Rosenwald A, Hurt EM, Petroulakis E, Sonenberg N, Yewdell JW, Calame K, Glimcher LH, Staudt LM (2004) XBP1, downstream of Blimp-1, expands the secretory apparatus and other organelles, and increases protein synthesis in plasma cell differentiation. Immunity 21:81-93. CrossRef Medline

Shen X, Ellis RE, Lee K, Liu CY, Yang K, Solomon A, Yoshida H, Morimoto R, Kurnit DM, Mori K, Kaufman RJ (2001) Complementary signaling pathways regulate the unfolded protein response and are required for $C$. elegans development. Cell 107:893-903. CrossRef Medline

Si L, Xu T, Wang F, Liu Q, Cui M (2012) X-box-binding protein 1-modified neural stem cells for treatment of Parkinson's disease. Neural Regen Res 7:736-740.

Sidrauski C, Cox JS, Walter P (1996) tRNA ligase is required for regulated mRNA splicing in the unfolded protein response. Cell 87:405-413. CrossRef Medline

Singleton AB, Farrer M, Johnson J, Singleton A, Hague S, Kachergus J, Hulihan M, Peuralinna T, Dutra A, Nussbaum R, Lincoln S, Crawley A, Hanson M, Maraganore D, Adler C, Cookson MR, Muenter M, Baptista M, Miller D, Blancato J, Hardy J, Gwinn-Hardy K (2003) Alpha-synuclein locus triplication causes Parkinson's disease. Science 302:841. CrossRef Medline

Sood R, Porter AC, Ma K, Quilliam LA, Wek RC (2000) Pancreatic eukaryotic initiation factor-2alpha kinase (PEK) homologues in humans, Drosophila melanogaster and Caenorhabditis elegans that mediate translational control in response to endoplasmic reticulum stress. Biochem J 346:281-293. CrossRef Medline

Stefanis L, Larsen KE, Rideout HJ, Sulzer D, Greene LA (2001) Expression of A53T mutant but not wild-type alpha-synuclein in PC12 cells induces alterations of the ubiquitin-dependent degradation system, loss of dopa- 
mine release, and autophagic cell death. J Neurosci 21:9549-9560. Medline

Tanaka N, Meineke B, Shuman S (2011) RtcB, a novel RNA ligase, can catalyze tRNA splicing and HAC1 mRNA splicing in vivo. J Biol Chem 286:30253-30257. CrossRef Medline

Tanaka Y, Engelender S, Igarashi S, Rao RK, Wanner T, Tanzi RE, Sawa A, Dawson L, Dawson TM, Ross CA (2001) Inducible expression of mutant alpha-synuclein decreases proteasome activity and increases sensitivity to mitochondria-dependent apoptosis. Hum Mol Genet 10:919-926. CrossRef Medline

Tarn WY, Steitz JA (1997) Pre-mRNA splicing: the discovery of a new spliceosome doubles the challenge. Trends Biochem Sci 22:132-137. CrossRef Medline

Thompson ML, Chen P, Yan X, Kim H, Borom AR, Roberts NB, Caldwell KA, Caldwell GA (2014) TorsinA rescues ER-associated stress and locomotive defects in C. elegans models of ALS. Dis Model Mech 7:233-243. CrossRef Medline

Uemura A, Oku M, Mori K, Yoshida H (2009) Unconventional splicing of XBP1 mRNA occurs in the cytoplasm during the mammalian unfolded protein response. J Cell Sci 122:2877-2886. CrossRef Medline

Urano F, Calfon M, Yoneda T, Yun C, Kiraly M, Clark SG, Ron D (2002) A survival pathway for Caenorhabditis elegans with a blocked unfolded protein response. J Cell Biol 158:639-646. CrossRef Medline

Uversky VN (2007) Neuropathology, biochemistry, and biophysics of $\alpha$-synuclein aggregation. J Neurochem 103:17-37. Medline

Valdés P, Mercado G, Vidal RL, Molina C, Parsons G, Court FA, Martinez A,
Galleguillos D, Armentano D, Schneider BL, Hetz C (2014) Control of dopaminergic neuron survival by the unfolded protein response transcription factor XBP1. Proc Natl Acad Sci U S A 111:6804-6809. CrossRef Medline

Vance C, Rogelj B, Hortobágyi T, Vos KJD, Nishimura AL, Sreedharan J, Hu X, Smith B, Ruddy D, Wright P, Ganesalingam J, Williams KL, Tripathi V, Al-Saraj S, Al-Chalabi A, Leigh PN, Blair IP, Nicholson G, de Belleroche J, Gallo JM, et al. (2009) Mutations in FUS, an RNA processing protein, cause familial amyotrophic lateral sclerosis type 6. Science 323:12081211. CrossRef Medline

Wan J, Yourshaw M, Mamsa H, Rudnik-Schöneborn S, Menezes MP, Hong JE, Leong DW, Senderek J, Salman MS, Chitayat D, Seeman P, von Moers A, Graul-Neumann L, Kornberg AJ, Castro-Gago M, Sobrido MJ, Sanefuji M, Shieh PB, Salamon N, Kim RC, et al. (2012) Mutations in the RNA exosome component gene EXOSC3 cause pontocerebellar hypoplasia and spinal motor neuron degeneration. Nat Genet 44:704-708. CrossRef Medline

Wang LK, Shuman S (2005) Structure-function analysis of yeast tRNA ligase. RNA 11:966-975. CrossRef Medline

Yacoubian TA, Standaert DG (2009) Targets for neuroprotection in Parkinson's disease. Biochim Biophys Acta 1792:676-687. CrossRef Medline

Yoshida H, Matsui T, Yamamoto A, Okada T, Mori K (2001) XBP1 mRNA is induced by ATF6 and spliced by IRE1 in response to ER stress to produce a highly active transcription factor. Cell 107:881-891. CrossRef Medline 